\title{
An Unusual Presentation of Peripheral Ossifying Fibroma in an Elderly Male - A Case Report
}

\author{
Shahira1 ${ }^{1}$ Biju Thomas ${ }^{2}$, Amitha Ramesh ${ }^{3}$, Santhosh Shenoy ${ }^{4}$, Anegundi Raghavendra Vamsi ${ }^{5}$ \\ 1, 2, 3, 4, 5 Department of Periodontology, A B Shetty Memorial Institute of Dental Sciences, \\ NITTE (Deemed to be University), Mangalore, Karnataka, India.
}

\section{INTRODUCTION}

Peripheral ossifying fibroma (POF) is a reactive process of the gingiva that develops due to irritation or minor trauma. Females are more affected than males suggesting a hormonal influence. This case report describes a case of peripheral ossifying fibroma in a 48-year-old male patient in 33, 34 regions in contrast to its common occurrence in young females. Histopathological examination is necessary to confirm the diagnosis. Surgical excision is the treatment of choice to prevent recurrence. One year follow up of the case showed no signs of recurrence.

Gingival overgrowth is a common feature of the various types of gingival disease in the oral cavity. Gingival diseases and conditions can be due to genetic disorder, specific infections, inflammatory and immune conditions and lesions, reactive processes, neoplasms, endocrine, nutritional, and metabolic diseases, traumatic lesions and gingival pigmentation. ${ }^{1}$ Reactive processes are non-neoplastic nodular swellings that develop in response to local irritation or minor trauma. The term epulis is exophytic processes confined to the gingiva. ${ }^{2} \mathrm{Kfir}$ et al. classified epulides into fibrous epulis, peripheral ossifying fibroma, pyogenic granuloma (vascular epulis), peripheral giant cell granuloma (or central). ${ }^{3}$

Ossifying fibromas in the oral cavity can be classified into central and peripheral type. The central type expands from the medullary cavity of the bone, arising from the endosteum or the periodontal ligament (PDL) adjacent to the root apex. Peripheral type arises from the soft tissues overlying the alveolar process which is contiguous with the periodontal ligament. ${ }^{4}$ This article presents a case of POF in a male patient.

\section{PRESENTATION OF CASE}

A 48-year- old male patient reported to the department of periodontics with the chief complaint of growth on the gums in relation to the lower left canine-premolar region since 4 months. Initially, it started with a small nodule and gradually increased to the present size. Growth was associated with bleeding on brushing and discomfort during mastication. (Figure 1) There was no relevant medical and dental history and patient did not give any history of trauma.

On intraoral examination, there was a solitary, reddish-pink, exophytic mass measuring about $0.9 \mathrm{~cm} \times 0.6 \mathrm{~cm} \times 0.5 \mathrm{~cm}$ with a yellowish patch on the surface. The growth was emerging from the buccal interdental papilla. It was extending from distal of 33 to mesial of 34, up to the level of the occlusal surface (Figure 2). The growth was firm with tenderness on palpation. There was no mobility of associated teeth. Therefore, a provisional diagnosis was given as irritation fibroma.

An intraoral periapical radiograph (IOPA) revealed no findings pertaining to the lesion. (Figure 3)

\section{DIFFERENTIAL DIAGNOSIS}

The differential diagnosis included irritation fibroma, pyogenic granuloma and peripheral giant cell granuloma.
Corresponding Author:

Dr. Biju Thomas,

Department of Periodontology,

A B Shetty Memorial Institute of Dental Sciences, NITTE (Deemed to be University), Mangalore - 575018,

Karnataka, India.

E-mail: bijunicy@yahoo.co.uk

DOI: $10.14260 / \mathrm{jemds} / 2021 / 579$

How to Cite This Article:

Shahira, Thomas B, Ramesh A, et al. An unusual presentation of peripheral ossifying fibroma in an elderly male - a case report. J Evolution Med Dent Sci 2021;10(33):2847-2850, DOI: $10.14260 /$ jemds $/ 2021 / 579$

Submission 31-03-2021, Peer Review 17-06-2021, Acceptance 22-06-2021, Published 16-08-2021.

Copyright (c) 2021 Shahira et al. This is an open access article distributed under Creative Commons Attribution License [Attribution 4.0 International (CC BY 4.0)] 


\section{DISCUSSION OF MANAGEMENT}

One week after phase-I therapy, there was no change in the size of the gingival overgrowth (Figure 4). After routine blood investigations, an excisional biopsy was done using the scalpel down to the periosteum. (Figure 5) The tissue was then sent for histopathological examination.
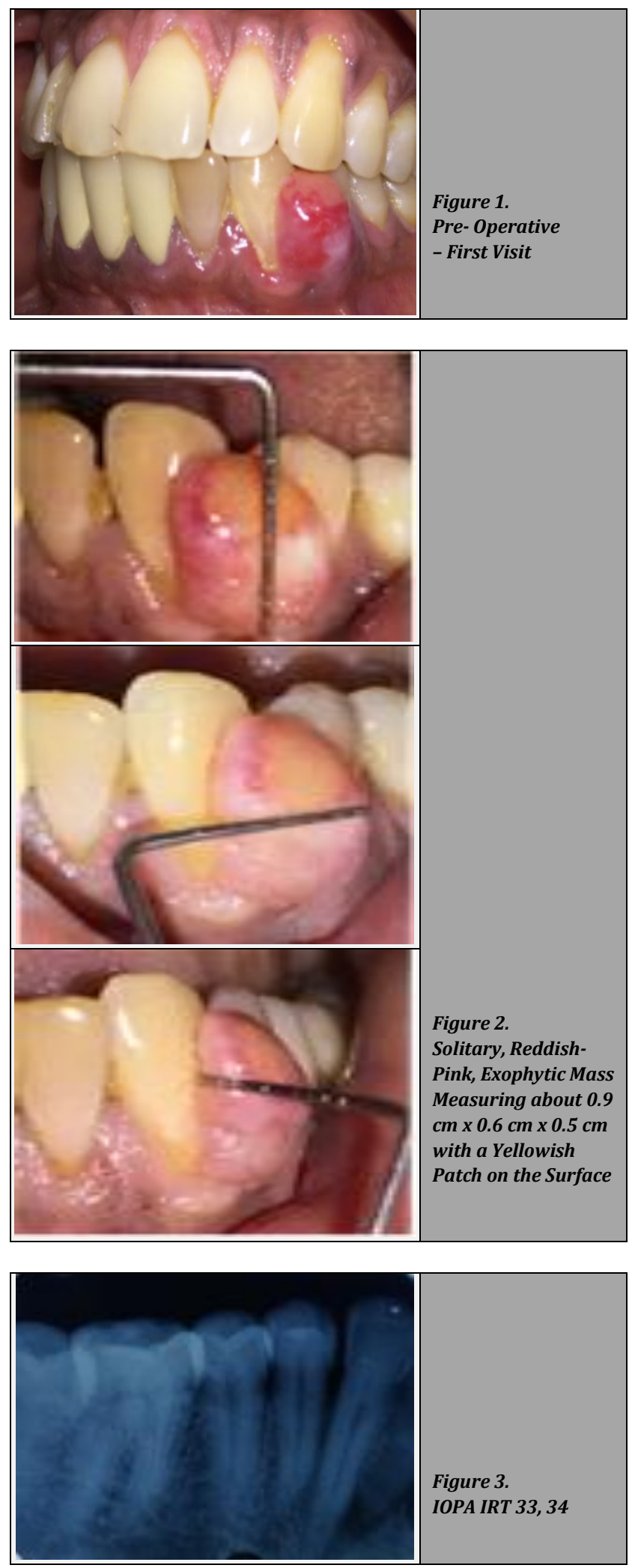
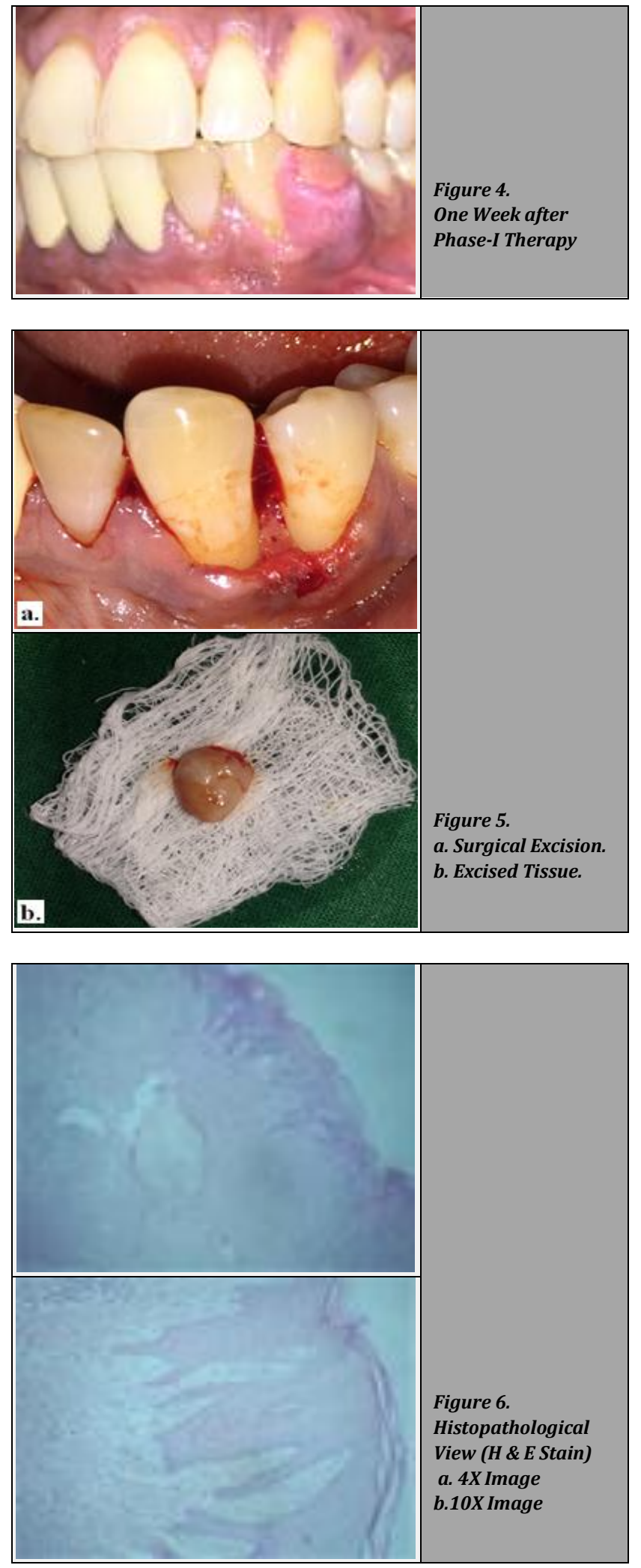

Histological examination of the haematoxylin \& eosin (H \& E) stained sections revealed epithelium and underlying connective tissue. The epithelium was stratified squamous parakeratinized epithelium of varying thickness. Areas of ulceration were seen with fibrous exudates and numerous capillaries with dense acute and chronic inflammatory cells chiefly neutrophils and lymphocytes. The underlying connective tissue was fibrous with dense bundles of collagen fibers and blood vessels. Focal calcification of varying size and number was evident and was surrounded by plump 
fibroblasts. (Figure 6) Thus, a final diagnosis of peripheral ossifying fibroma with respect to 33 and 34 regions was established.

After 15 days, the surgical site showed satisfactory healing. The case was followed up for a period of 1 year, and had shown normal healing with no signs of recurrence. (Figure 7)

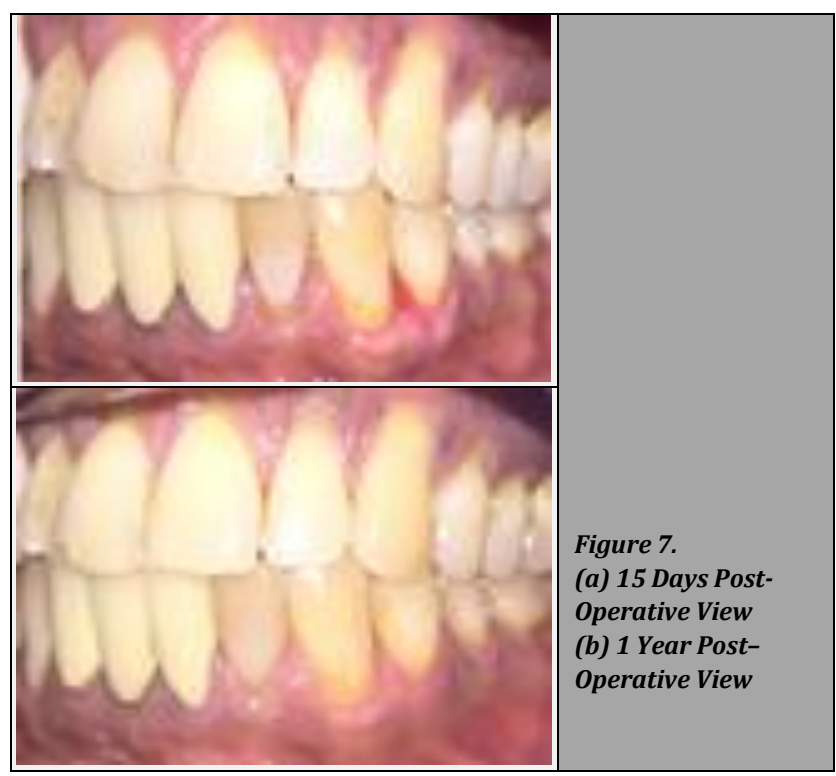

\section{DISCUSSION}

POF is a solitary, slow-growing, nodular gingival overgrowth originating from cells of the PDL and periosteum. ${ }^{5}$ It occurs mostly on the maxillary and mandibular gingiva, anterior to the molars emerging from the interdental papilla. ${ }^{6}$ In this case report, the origin of overgrowth was considered as cells of PDL because of the proximity of gingiva (interdental papilla) to PDL and the presence of dense collagen fibers.

In 1972, Eversole and Rovin described POF as a reactive lesion of gingiva. In 1982, Gardner coined the term POF. ${ }^{7}$ A lesion may develop as a result of trauma or local irritants such as subgingival plaque and calculus, dental appliances, faulty dental restorations, food lodgements and iatrogenic factors. ${ }^{8}$ In this case, it could be due to the presence of subgingival plaque and calculus which was evident on the first visit. The lesion is usually smaller than $1.5 \mathrm{~cm}$ in diameter with an ulcerated surface. The base of the lesion is either pedunculated or sessile. ${ }^{9}$ This lesion generally affects females in the second or third decade of life. ${ }^{10}$ However, in this case, POF occurred in an aged male patient which contradicts the concept of hormonal influence in the aetiology of the disease.

In this case, the clinical features led to the differential diagnosis of irritation fibroma, pyogenic granuloma or peripheral giant cell granuloma. However, confirmatory diagnosis of POF was made based on the histopathological examination which is characterized by ulcerated stratified squamous surface epithelium, a high degree of cellularity, acute and chronic inflammatory cells, and dystrophic calcification. ${ }^{11}$ Pyogenic granuloma is more vascular than POF. Peripheral giant cell granuloma is less cellular and contains giant cells when compared to POF.12 Various other terminologies of POF are calcifying fibroblastic granuloma, peripheral fibroma with calcification, ossifying fibroid epulis, and peripheral cementifying fibroma. ${ }^{13}$

The management of POF is by the elimination of local irritants and surgical excision of the lesion including the underlying periosteum. ${ }^{14}$ The recurrence rate of POF is $8-20$ $\%$, which can be due to the incomplete removal of the growth. 15
Abbreviations
1. POF - Peripheral ossifying fibroma
2. PDL - Periodontal ligament.
3. IOPA- Intraoral periapical radiograph
4. H \& E - Haematoxylin \& eosin

\section{CONCLUSIONS}

A slowly progressing growth, anterior to the molar region in an elderly male patient with high degree of cellularity, inflammatory cells and dystrophic calcification confirmed the diagnosis of POF. Therefore, it is important for clinicians to think out of the box as regards the aetiology of POF.

Financial or other competing interests: None.

Disclosure forms provided by the authors are available with the full text of this article at jemds.com.

\section{REFERENCES}

[1] Holmstrup P, Plemons J, Meyle J. Non-plaque-induced gingival diseases. J Clin Periodontol 2018;45(Suppl 20):28-43.

[2] Naderi NJ, Eshghyar N, Esfehanian H. Reactive lesions of the oral cavity: a retrospective study on 2068 cases. J Dent Res 2012;9(3):251-5.

[3] Kfir Y, Buchner A, Hansen LS. Reactive lesions of the gingiva: a clinicopathological study of 741 cases. J Periodontol 1980;51(11):655-61.

[4] Bhasin M, Bhasin V, Bhasin A. Peripheral ossifying fibroma. Case Rep Dent 2013;2013:497234.

[5] Ramu S, Rodrigues C. Reactive hyperplastic lesions of the gingiva: a retrospective study of 260 cases. World J Dent 2012;3(2):126-30.

[6] Raj PR, Nausheen E, Rawther NN, et al. Peripheral ossifying fibroma of the posterior maxilla: a rare case report. Int J Sci Res 2015;3(6):217-20.

[7] Horwitz J, Akrish S, El Naaj I. Surgical management of recurrent peripheral ossifying fibroma. Clinical Advances in Periodontics 2014;15:1-21.

[8] Nanda R, Chhabra R, Shamsi AM, et al. Peripheral ossifying fibroma: a case report. Int J Dent Med Res 2014;1(3):668.

[9] Arunachalam M, Saravanan T, Shakila KR, et al. Peripheral ossifying fibroma: a case report and brief review. SRM J Res Dent Sci 2017;8(1):41-5.

[10] Zhang W, Chen Y, An Z, et al. Reactive gingival lesions: a retrospective study of 2,439 cases. Quintessence Int 2007;38(2):103-10. 
[11] De Marcos JAG, De Marcos MJG, Rodríguez SA, et al. Peripheral ossifying fibroma: a clinical and immunohistochemical study of four cases. J Oral Sci 2010;52(1):95-9.

[12] Hunasgi S, Koneru A, Vanishree M, et al. Assessment of reactive gingival lesions of oral cavity: a histopathological study. J Oral Maxillofac Pathol 2017;21(1):180.
[13] Karmakar S, Srinath R, Prakash S. A novel approach for the treatment of peripheral ossifying fibroma: a case report with 1-Year follow-up. J Dent Lasers 2018;12(1):36-40.

[14] Farquhar T, Maclellan J, Dyment H, et al. Peripheral ossifying fibroma: a case report. J Can Dent Assoc 2008;74(9):809-12.

[15] Chhina S, Gakhar A, Mavi S, et al. Peripheral ossifying fibroma: a case report \& review of literature. IJSS Case Rep Rev 2015;1:61-4. 